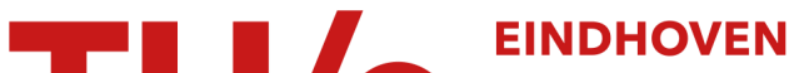 UNIVERSITY OF TECHNOLOGY
}

\section{Parameters affecting the synthesis of titanium silicalite 1}

Citation for published version (APA):

vd Pol, A. J. H. P., \& Hooff, van, J. H. C. (1992). Parameters affecting the synthesis of titanium silicalite 1. Applied Catalysis. A, General, 92(2), 93-111. https://doi.org/10.1016/0926-860X(92)80309-Z

DOI:

10.1016/0926-860X(92)80309-Z

Document status and date:

Published: 01/01/1992

\section{Document Version:}

Publisher's PDF, also known as Version of Record (includes final page, issue and volume numbers)

\section{Please check the document version of this publication:}

- A submitted manuscript is the version of the article upon submission and before peer-review. There can be important differences between the submitted version and the official published version of record. People interested in the research are advised to contact the author for the final version of the publication, or visit the $\mathrm{DOI}$ to the publisher's website.

- The final author version and the galley proof are versions of the publication after peer review.

- The final published version features the final layout of the paper including the volume, issue and page numbers.

Link to publication

\section{General rights}

Copyright and moral rights for the publications made accessible in the public portal are retained by the authors and/or other copyright owners and it is a condition of accessing publications that users recognise and abide by the legal requirements associated with these rights.

- Users may download and print one copy of any publication from the public portal for the purpose of private study or research.

- You may not further distribute the material or use it for any profit-making activity or commercial gain

- You may freely distribute the URL identifying the publication in the public portal.

If the publication is distributed under the terms of Article $25 \mathrm{fa}$ of the Dutch Copyright Act, indicated by the "Taverne" license above, please follow below link for the End User Agreement:

www.tue.nl/taverne

Take down policy

If you believe that this document breaches copyright please contact us at:

openaccess@tue.nl

providing details and we will investigate your claim. 


\title{
Parameters affecting the synthesis of titanium silicalite 1
}

\author{
A.J.H.P. van der Pol and J.H.C. van Hooff \\ Eindhoven University of Technology, Laboratory of Inorganic Chemistry and Catalysis, \\ P.O. Box 513, 5600 MB Eindhoven (Netherlands)
}

(Received 15 June 1992, revised manuscript received 11 September 1992)

\begin{abstract}
The influence of the $\mathrm{SiO}_{2}$ source, crystallization time, stirred and static crystallization conditions, TPAOH source, $\mathrm{OH}^{-} / \mathrm{Si}$ ratio, $\mathrm{Si} / \mathrm{Ti}$ ratio and sol concentration were studied. Crystallizations were carried out at $175^{\circ} \mathrm{C}$ in teflon-lined autoclaves. We were able to synthesize well shaped, homogeneous, highly crystalline batches of TS-1 zeolites with Si/Ti ratio ranging from 24 to infinity $(0$ to $4 \mathrm{~mol}-\%$ $\mathrm{Ti}$ ) and a crystallite size ranging from 0.09 to $12 \mu \mathrm{m}$. In order to form small crystallites, seeds are added and the reaction mixture is agitated during crystallization. The best conditions to form small crystallites are; high silicon concentration, low $\mathrm{OH}^{-}$concentration and low water concentration.
\end{abstract}

Keywords: TS-1, Titanium silicalite-1, synthesis, crystallization, zeolites.

\section{INTRODUCTION}

Titanium Silicalite-1 (TS-1) has very interesting properties as an oxidation catalyst, as mentioned in a number of patents and papers about oxidation of aromatics [1-3], alkanes [4,5], alkenes [6-8] and alcohols [9,10]. TS-1 is developed by Enichem research workers in 1983 and is used commercially in the hydroxylation of phenol since 1986 . This catalyst has very promising properties in fine chemical oxidations and condensations [11,12].

A large number of articles have been written about the preparation of silicalite and Al-silicalite [13-15] but the incorporation of titanium into this structure asks for a completely different approach. Because titanium ions are not stable at the high $\mathrm{pH}$ values normally used in zeolite synthesis, they will form a very stable $\mathrm{TiO}_{2}$ phase which does not dissolve to $\mathrm{Ti}(\mathrm{OH})_{4}$ species, as silicon, aluminium and for example gallium would do. Therefore, a completely different synthesis route must be used to prevent the formation of this stable

Correspondence to: D.A.J.H.P. van der Pol, Eindhoven University of Technology, Laboratory of Inorganic Chemistry and Catalysis, P.O. Box 513, 5600 MB Eindhoven, Netherlands. Tel. (+3140)474952, fux. (+31-40)455054, e-mail TGTAMP@CHEM.TUE.NL. 
$\mathrm{TiO}_{2}$ phase. To understand the problems of this difficult zeolite synthesis we investigated extensively the influence of different synthesis parameters on the preparation of active TS-1.

The basic preparation method of the crystallization sol is a slight modification of the procedure described in the patents of Taramasso et al. [16] and Bellusi et al. [17]. In this article the influence of silica source, crystallization time, stirred/static conditions and the addition of seeds, TPAOH source, $\mathrm{TPAOH} / \mathrm{Si}$ ratio, $\mathrm{Si} / \mathrm{Ti}$ ratio and sol concentration will be described.

The formation of TS-1 is followed by X-ray diffraction (XRD), infrared spectroscopy (IR) and scanning electron microscopy (SEM), while the catalytic properties are tested by means of the hydroxylation of phenol and the epoxidation of octene and hexene with hydrogen peroxide. The phenol hydroxylation is most interesting, because this reaction is very sensitive to tar formation, and therefore puts the highest demands on the catalysts used. This is the reaction were optimal use is made of the properties of TS-1 and therefore this reaction is used to determine the quality of the different samples.

\section{EXPERIMENTAL}

All the zeolite syntheses were carried out (stirred or static) in teflon-lined autoclaves (volume 100 to $2000 \mathrm{ml}$ ) at $175^{\circ} \mathrm{C}$ under autogenous pressure. The autoclaves were loaded to $80 \%$ capacity. Two silicon sources were used, Ludox AS-40 commercial silica sol from Du Pont and tetraethyl orthosilicate (TEOS) from Merck. As titanium source was used tetraethyl orthotitanate (TEOT) from Merck (incidentally tetraisopropyl orthotitanate was used but no differences were found in the resulting products). As templates were used TPABr (from Aldrich) mixed with $\mathrm{NaOH}$, TPAOH home made from TPABr by ion exchange over a anion exchanger (Dowex-1) and three commercial available TPAOH sources from Aldrich, Alfa and Fluka. Doubly distilled water or AAS grade water was used.

In order to investigate the crystallization phenomenon small samples were taken from a 500-ml autoclave at different times $(2,4,6,8,10$ days $)$. The solid products were isolated by means of filtration or centrifugation, washed free from alkali and dried at $70^{\circ} \mathrm{C}$ overnight. The degree of crystallinity of the samples was evaluated by XRD. The morphology of the different samples was investigated using scanning electron microscopy.

The two procedures used to prepare the TS-1 sol were slightly different from example 1 and 2 mentioned in the literature [16]. However, as the sol preparation is the essential part of the preparation of TS- 1 and much more critical than the preparation of a Al-ZSM-5 or Ga-ZSM-5 gel it will be described more extensively. 
Method 1: (Recipe to prepare TS-1 with $\mathrm{Si} / \mathrm{Ti}=70$ and $\mathrm{OH}^{-} / \mathrm{Si}=0.43$ )

An amount of $257.9 \mathrm{~g}$ of TEOS containing $1.238 \mathrm{~mol}$ of silicon was trangferred to a teflon beaker and vigorously stirred, $4.0 \mathrm{ml}$ of TEOT containing $0.0177 \mathrm{~mol}$ of titanium was carefully dripped into this TEOS. The teflon beaker was closed with Parafilm and nitrogen was flushed over to prevent carbon dioxide absorption. The temperature was raised to $35^{\circ} \mathrm{C}$ and the reactants were mixed homogeneously for half an hour to obtain depolymerisation of the titanate oligomers that may be present in TEOT. Then the mixture was cooled to about $0^{\circ} \mathrm{C}$. The TPAOH solution, which was used as template, was also cooled to $0^{\circ} \mathrm{C}$. After a few minutes, $533.0 \mathrm{~g}$ of a $20 \%$ aqueous solution of TPAOH containing $0.527 \mathrm{~mol}$ TPAOH was very slowly added drop-wise into the mixture of TEOS and TEOT. At first, one should wait a few minutes after each addition of a few drops of TPAOH solution before more TPAOH solution is added. Stirring and cooling should be continued during this process. After the addition of about $10 \mathrm{ml}$ the addition rate of TPAOH solution could be sped up. If a white, gelatinous precipitate is formed one should wait until this has disappeared. If the precipitate has not disappeared after $10 \mathrm{~min}$, some extra TPAOH solution should be added in order to dissolve the precipitate. If the precipitate does not dissolve, amorphous $\mathrm{TiO}_{2}$ has been formed and the synthesis has failed (TPAOH has been added too fast or TEOS and TEOT have not been mixed sufficiently). If no precipitate is formed the slow addition of TPAOH can be continued. After addition of all TPAOH the crystallization mixture can be heated in about one hour to a temperature in the range of 80 $90^{\circ} \mathrm{C}$. The mixture was kept for 3 to $5 \mathrm{~h}$ at this temperature (while stirring) in order for the hydrolysis of TEOS and TEOT to take place. Distilled water was added to increase the volume of the mixture to its original value of about $0.85 \mathrm{l}$. At the end the solution must still be clear (no gel formation). This clear solution can be transferred into a 1-l autoclave. The autoclave was heated to $175^{\circ} \mathrm{C}$ for different times and with or without stirring (ca. $120 \mathrm{rpm}$ ), to obtain crystallization.

\section{Method 2: (recipe to prepare TS-1 with $\mathrm{Si} / \mathrm{Ti}=49$ and $\mathrm{OH}^{-} / \mathrm{Si}=0.27$ )}

An amount of $4.0 \mathrm{ml}$ of TEOT containing $0.0177 \mathrm{~mol} \mathrm{Ti}$ was slowly added drop-wise into $360 \mathrm{ml}$ doubly distilled water under stirring. The TEOT immediately formed a white gelatinous precipitate. This suspension was cooled to $5^{\circ} \mathrm{C}$. After a few minutes $48.6 \mathrm{ml}$ of $36 \% \mathrm{H}_{2} \mathrm{O}_{2}$ containing $0.717 \mathrm{~mol} \mathrm{H}_{2} \mathrm{O}_{2}$ was added (also at $5^{\circ} \mathrm{C}$ ). The colour of the suspension changed from white via yellow to orange until after two hours of stirring at this low temperature a clear orange solution was obtained (the white precipitate had dissolved). Then 240.0 $\mathrm{ml}$ of a $20 \%$ aqueous solution of TPAOH containing $0.239 \mathrm{~mol}$ TPAOH and $360 \mathrm{ml} \mathrm{H}_{2} \mathrm{O}$ was slowly added under continuous stirring at $5^{\circ} \mathrm{C}$. After $30 \mathrm{~min}$ 
$144 \mathrm{ml}$ of Ludox AS-40 colloidal silica sol containing $0.872 \mathrm{~mol} \mathrm{Si}$ was added. This mixture was stirred overnight. The following day it was heated to $70-$ $80^{\circ} \mathrm{C}$ and stirred for another 6-7 h. Then the mixture was transferred to a 1-l autoclave and heated to $175^{\circ} \mathrm{C}$ for different times with or without stirring.

The products were identified by X-ray powder diffraction using a Philips PW 7200 spectrophotometer. The crystalline phase present in the sample was determined quantitatively by comparing the solid product with a standard sample.

The infrared spectra of the formed products were obtained using the $\mathbf{K B r}$ wafer technique in a Hitachi 270-30 infrared spectrophotometer. Scanning electron micrographs were obtained by using a Jeol-840 A scanning microscope with an energy-dispersive X-ray (EDX) analyzer.

Gravimetric sorption experiments were carried out in a Setaram TG-85 model 16-18 system.

The chemical analyses were done by means of AAS using a Perkin Elmer 3030 atomic absorption spectrophotometer. The protocol was to digest approximately $100 \mathrm{mg}$ of a sample with $\mathrm{H}_{2} \mathrm{SO}_{4}$ and $\mathrm{HF}$. The samples were diluted until all samples fell in the linear range of the standard addition method.

The samples were calcined in a stream of air at $550^{\circ} \mathrm{C}$ for $3 \mathrm{~h}$ before they were used as catalyst.

\section{RESULTS AND DISCUSSION}

\section{Crystallization time}

In the Enichem patent [16] is mentioned that crystallization times of minimal ten days are necessary. Because this is a rather long time we investigated if this crystallization time could be shortened. Two crystallization mixtures were prepared, one according to method 1 and the other according to method 2 (for the compositions see Table 1 ).

The crystallization process is studied by means of physical techniques (XRD, IR and SEM) and by a chemical technique (the catalytic activity in the phenol hydroxylation reaction). Samples were taken after $2,4,6,8$, and 10 days.

From XRD measurements can be seen that after two days a completely crys-

\section{TABLE 1}

Sol composition of time dependent experiments

\begin{tabular}{llllll}
\hline & $\mathrm{Si} / \mathrm{Ti}$ & $\mathrm{OH}^{-/ \mathrm{Si}}$ & $\begin{array}{l}\mathrm{Ti} \\
(\mathrm{mol} / \mathrm{l})\end{array}$ & $\begin{array}{l}\mathrm{Si} \\
(\mathrm{mol} / \mathrm{l})\end{array}$ & $\begin{array}{l}\mathrm{OH}^{-} \\
(\mathrm{mol} / \mathrm{l})\end{array}$ \\
\hline Method 1 & 33.3 & 0.35 & 0.068 & 2.26 & 0.79 \\
Method 2 & 36.0 & 0.38 & 0.060 & 2.00 & 0.63 \\
\hline
\end{tabular}




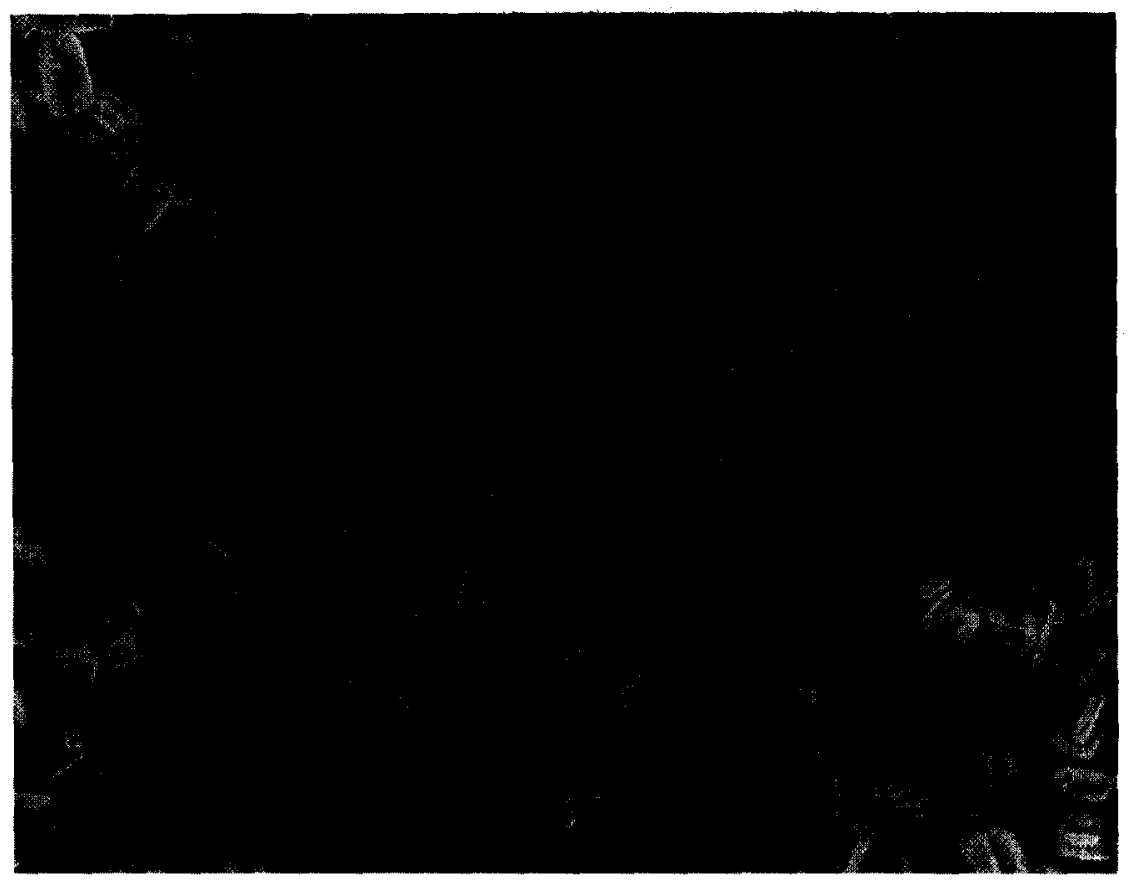

Fig. 1. SEM picture of elongated crystallites obtained by synthesis method 2.

talline product had formed. For longer crystallization times no increase in crystallinity was observed. Also no new peaks appeared, therefore it can be concluded that the TS- 1 is stable in the mother liquor at $175^{\circ} \mathrm{C}$ (no other phases were formed). No changes in intensities were found, so that the possibility of growth of specific surfaces can be excluded as well.

From infrared experiments no changes in the spectra after two days were seen. The absorption at $960 \mathrm{~cm}^{-1}$ assigned to titanium in the zeolite lattice did not change after two days. The intensity of the $960 \mathrm{~cm}^{-1}$ peak is nearly the same for both samples.

From SEM no growth of the crystallite size after two days was found. The crystallites formed according to method 1 were $0.2 \mu \mathrm{m}$ and those made according to method 2 were $8 \mu \mathrm{m}$, and neither grows after two days. The catalytic activity of the different batches formed after two days of crystallization is the same as for those formed after ten days. From the time dependent experiments it can be concluded that a crystallization time of two days is enough and that a crystallization time of ten days or more, as mentioned in the literature, is not necessary.

The main difference between the two preparation methods is the silicon sources used. In method 1, tetraethyl orthosilicate (TEOS) which is a monomeric silicon source (tested by ${ }^{29} \mathrm{Si}$ MAS-NMR) is used and in method 2, Lu- 
TABLE 2

Sol composition of the samples which were prepared to test for the influence of stirred conditions (-A), static conditions (-B) and the addition of seeds (-C).

\begin{tabular}{llllll}
\hline Sample & $\mathrm{Si} / \mathrm{Ti}$ & $\mathrm{OH}-/ \mathrm{Si}$ & $\begin{array}{l}{[\mathrm{Ti}]} \\
(\mathrm{mol} / \mathrm{l})\end{array}$ & $\begin{array}{l}{[\mathrm{Si}]} \\
(\mathrm{mol} / \mathrm{l})\end{array}$ & $\begin{array}{l}{[\mathrm{OH}]} \\
(\mathrm{mol} / \mathrm{l})\end{array}$ \\
\hline TS-10-A & 10.5 & 0.786 & 0.115 & 1.21 & 0.948 \\
TS-10-C & 10.5 & 0.786 & 0.115 & 1.21 & 0.948 \\
TS-35-AA & 33.5 & 0.35 & 0.068 & 2.26 & 0.790 \\
TS-35-B & 33.3 & 0.35 & 0.068 & 2.26 & 0.790 \\
TS-70-A & 64.2 & 0.405 & 0.022 & 1.44 & 0.582 \\
TS-70-B & 64.2 & 0.405 & 0.022 & 1.44 & 0.582 \\
TS-70-C & 64.2 & 0.405 & 0.022 & 1.44 & 0.582 \\
\hline
\end{tabular}

Short description of the samples:

TS-10-A: Two kind of crystallites are formed, large twinned coffins of approximately $12 \mu \mathrm{m}$ and small spherical crystallites of about $0.6 \mu \mathrm{m}$. Nearly no other forms are found.

TS-10-C: Coffins of $3 \mu \mathrm{m}$.

TS-35-AA: Cubic crystallites of about $0.17 \mu \mathrm{m}$, very homogeneous, no coffins.

TS-35-B: Cubic crystallites of approximately $0.17 \mu \mathrm{m}$ with a little rounding of the edges and some perfect coffins of about $0.6 \mu \mathrm{m}$ (number fraction $<0.1 \%$ ).

TS-70-A: Cubic crystallites of about $0.2 \mu \mathrm{m}$ and some hexagonal crystallites of the same size. Very homogeneous batch.

TS-70-B: Very homogeneous batch of $0.2 \mu \mathrm{m}$ cubic crystallites with a little rounded edges. Nearly no coffins are formed.

TS-70-C: Very neat crystallites, mostly cubic with some hexagonal ones. No coffins. Crystallite size $0.2 \mu \mathrm{m}$.

dox AS- 40 commercial silica with particle size of $22 \mathrm{~nm}$, a specific surface area of $140 \mathrm{~m}^{2} / \mathrm{g}$ and a pH of 9.2 , which is a polymeric silicon source (tested by ${ }^{29} \mathrm{Si}$ MAS NMR) is used.

If TEOS is used as a silicon source a high effective concentration of $\mathrm{Si}(\mathrm{OH})_{4}$ monomers is formed and if Ludox, which consists of large agglomerates of $\mathrm{SiO}_{2}$, is used as a silicon source, a low monomeric concentration of $\mathrm{Si}(\mathrm{OH})_{4}$ is formed. TEOS is used in TS-1 preparations which follow the procedure described in method 1 . This method gives crystallites from 0.1 to $15 \mu \mathrm{m}$ depending on $\mathrm{OH}^{-}$and Si concentration (vide infra). Ludox AS-40 is used in TS-1 preparations as described in method 2 . This normally leads to large, elongated crystallites (see Fig. 1). Only when Ludox is first mixed with TPAOH for a long time ( 1 day), and then added to the titanium in $\mathrm{H}_{2} \mathrm{O}_{2} / \mathrm{H}_{2} \mathrm{O}$ solution, small crystallites can be formed. In this way the Ludox agglomerates are first partly dissolved to monomers so that the $\mathrm{Si}(\mathrm{OH})_{4}$ concentration is raised (checked by ${ }^{29} \mathrm{Si}$ MAS NMR) and thus more nucleation nuclei are formed and thus smaller crystallites. From these experiments it can be concluded that high concentrations of monomers are necessary to produce small crystallites and that the easiest way to prepare small crystallites is described in method 1 which 
makes use of TEOS. When reactions were carried out with the TS-1 samples a large difference in activity between the batch prepared according to method 1 and the batch prepared according to method 2 was found. Because the samples prepared according to method 1 were in all cases the most active, we decided to restrict our research to method 1.

Stirred [A], static [B] conditions and the addition of seeds [C]

An amount of 2.5 litre of reaction sol was prepared and split in three parts. The main part was put in a stirred autoclave (sample TS-70-A), a small part was put in a static autoclave (sample TS-70-B) and the third part (to which seeds (TS-35-AA) were added, $1 \mathrm{wt}$ - $\%$ ) was put into a stirred autoclave (sample TS-70-C). See Table 2 for a description of the samples. The difference between the three crystallization products was very minor. Using XRD no difference could be observed (see Fig. 2) and using SEM, under very large magnification, only a slight rounding of the edges of the cubic crystallites (of 0.2 $\mu \mathrm{m}$ ) prepared in static crystallization, could be seen (see Fig. 3), which was absent when the crystallization mixture had been stirred. In this case the ad-

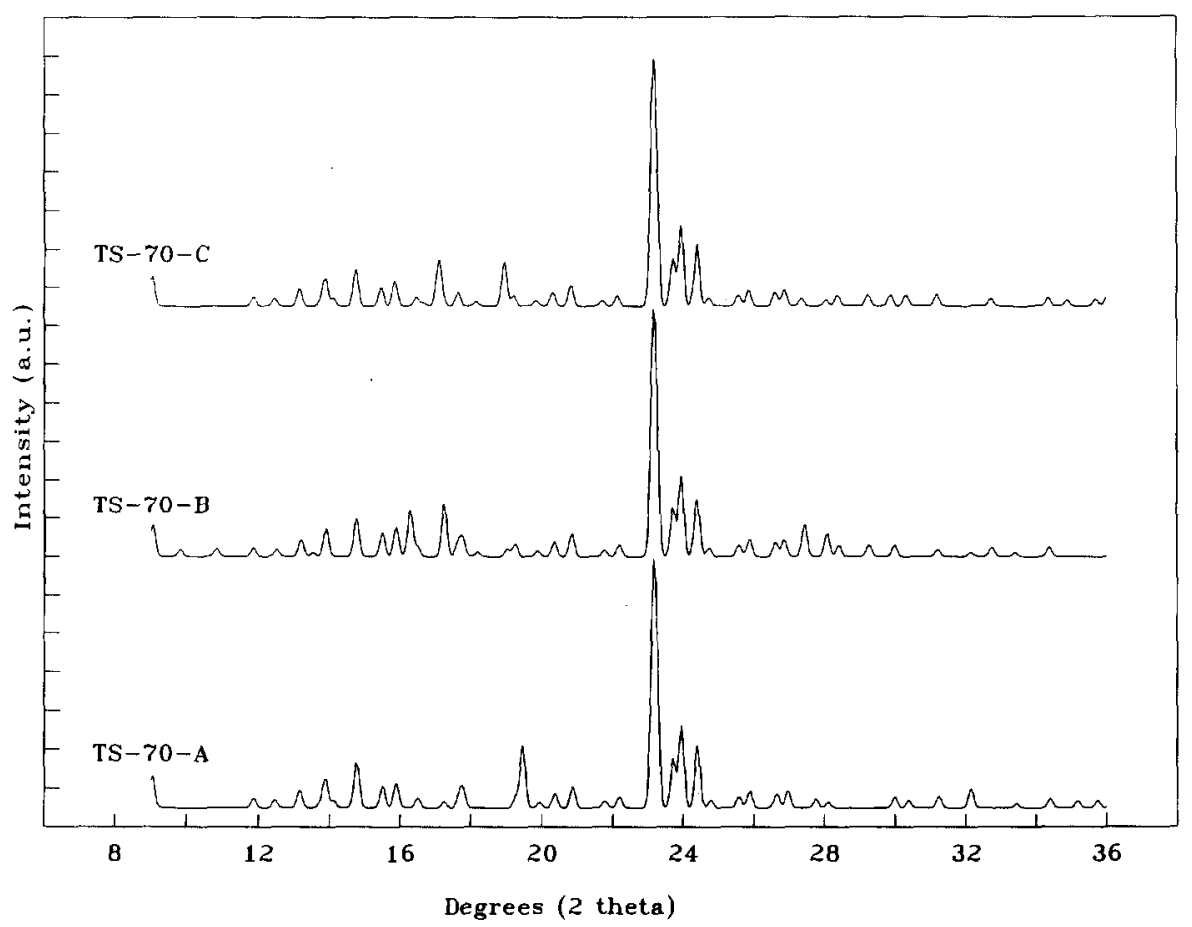

Fig. 2. XRD spectra of batch TS-70-A, TS-70-B and TS-70-C. 

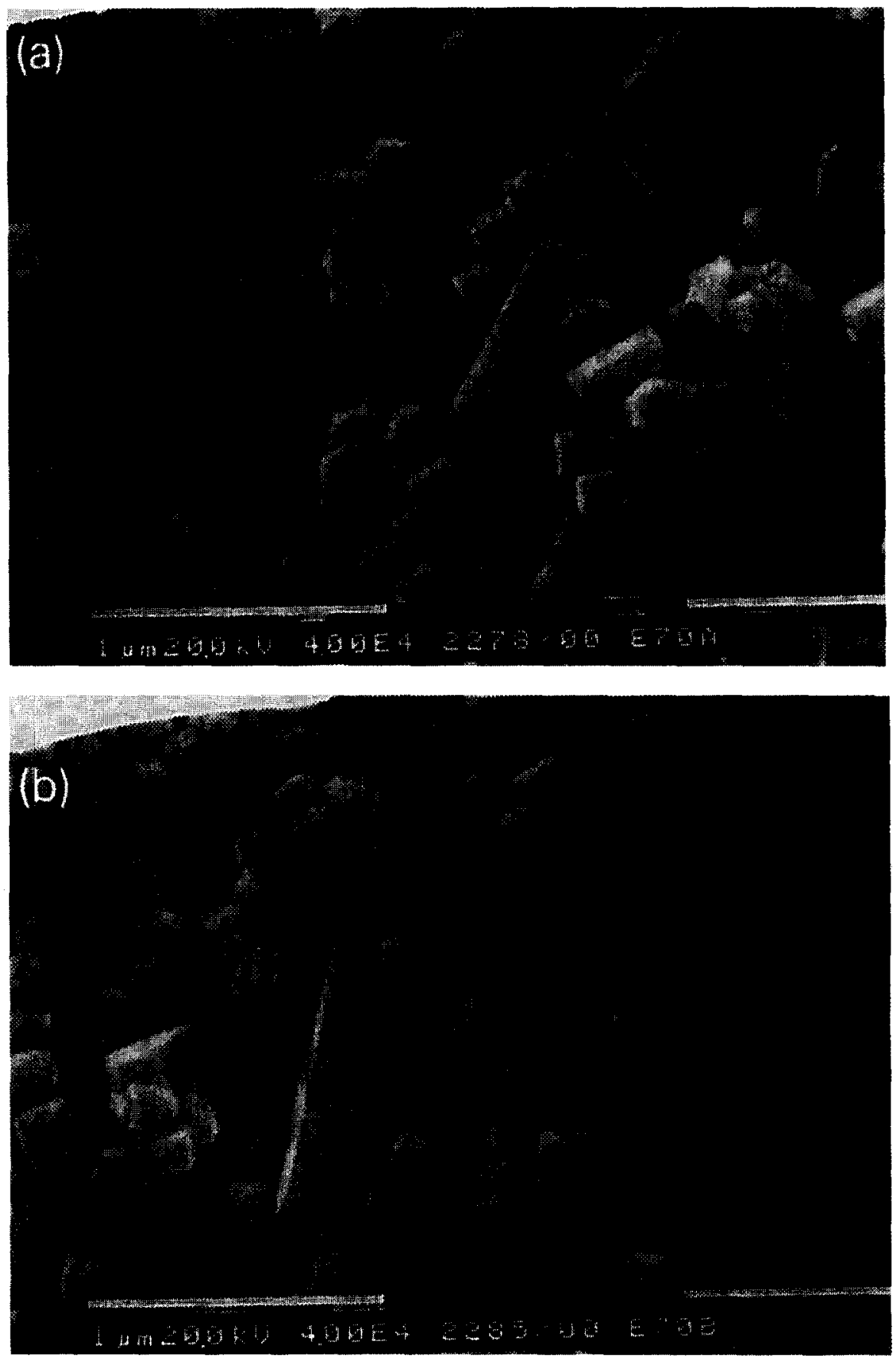

Fig. 3. SEM picture of (a) TS-70-A (stirred) and (b) TS-70-B (static). 
TABLE 3

Different amounts of $\mathrm{Na}^{+}$and $\mathrm{K}^{+}$in the five different $\mathrm{TPAOH}$ sources

\begin{tabular}{lccc}
\hline & $\begin{array}{l}\mathrm{Na}^{+} \\
(\mathrm{ppm})\end{array}$ & $\begin{array}{l}\mathrm{K}^{+} \\
(\mathrm{ppm})\end{array}$ \\
\hline TPAOH-NaOH & 23000 & n.d. \\
TPAOH-DOWEX & $<40$ & n.d. \\
TPAOH-Aldrich & 220 & 600 \\
TPAOH-Alfa & 135 & 1 \\
TPAOH-Fluka & 400 & 5400 \\
\hline
\end{tabular}

n.d. Not determined.

dition of seeds had no effect. This might be due to the very small size of the crystallites which are formed if no seeds are available. Under the circumstances when normally crystallites of about $12 \mu \mathrm{m}$ (TS-10-A, see Table 2) would be formed, it can be seen that, if seeds ( $1 \mathrm{wt.} . \%)$ are added, the average crystallites size decreases to about $3 \mu \mathrm{m}$ (TS-10-C, see Table 2). In that case seeds do have a strong effect on the average crystallite size. After this series of experiments we decided to do all following experiments under stirred conditions and without seeds.

\section{TPAOH source}

Five different TPAOH sources are used: TPAOH from Aldrich (20\% solution in water), TPAOH from Alfa ( $40 \%$ solution in water), TPAOH from Fluka (20\% solution in water), TPAOH made by mixing $\mathrm{TPABr}$ and $\mathrm{NaOH}$, and TPAOH home made from TPABr by means of ion exchange over a cation exchanger (DOWEX-1).

In the patent of Enichem [16] is described that alkali and alkaline earth metals have a negative influence on the synthesis of TS-1. We obtained good results with TPAOH solutions commercially available from Alfa, Aldrich and Fluka in which only small amounts of $\mathrm{Na}^{+}$and $\mathrm{K}^{+}$could be detected by AAS and/or flame photometry (see Table 3). Addition of $\mathrm{NaOH}$ to these template solutions led to the formation of inferior products.

Good results could also be obtained when using TPAOH solutions prepared by passing a TPABr solution over a column containing DOWEX-1 anion exchanger.

After this series of experiments we decided to use TPAOH from Alfa as templating agent in the rest of our experiments. 

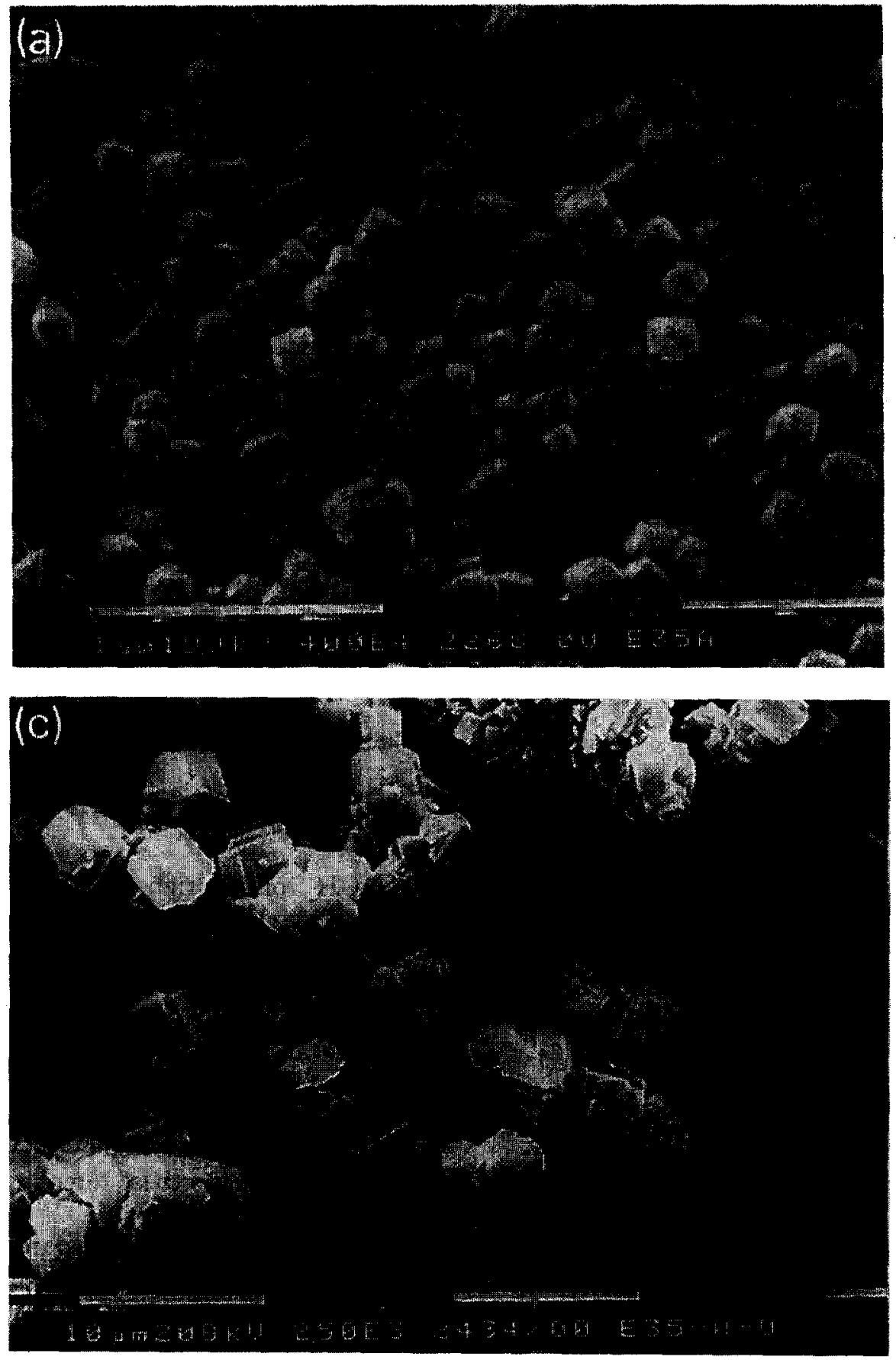

Fig. 4. SEM picture of (a) TS-35-AA, (b) TS-35-AB and (c) TS-35-AC. 


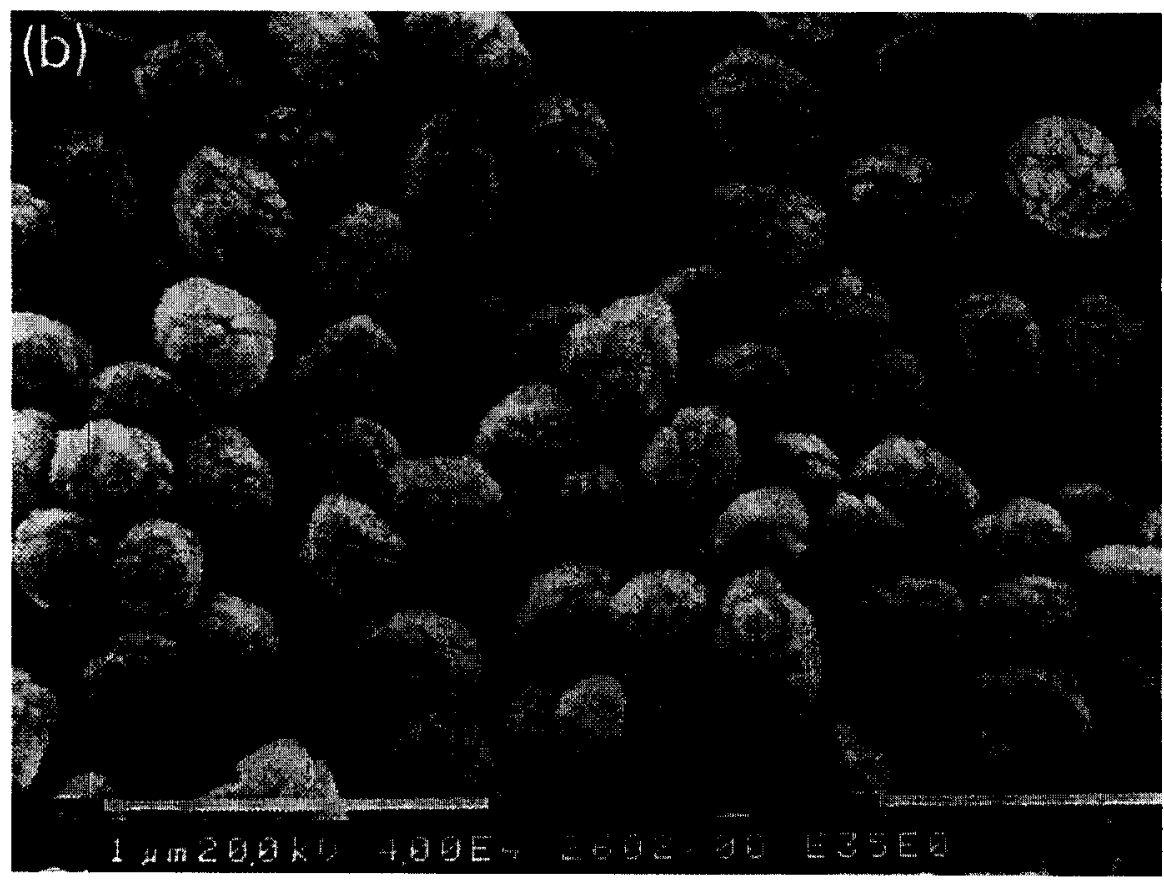

\section{Influence of the TPAOH/Si ratio}

SEM pictures showed small particles of approximately $0.3 \mu \mathrm{m}$ at $\mathrm{OH}^{-} /$ $\mathrm{Si}=0.22$ (see Fig. 4c, sample TS-35-AC). These particles were not neatly crystallized, the outer surface was covered with amorphous gel. If the $\mathrm{OH}^{-} / \mathrm{Si}$ ratio was raised to 0.35 the amorphous layers disappeared and the crystallite size decreased to about $0.17 \mu \mathrm{m}$ (see Fig. 4a, sample TS-35-AA, very neat cubic crystallites). If the $\mathrm{OH}^{-} / \mathrm{Si}$ ratio was further increased to 0.53 the crystallite size also strongly increased to about $4 \mu \mathrm{m}$ (see Fig. $4 \mathrm{~b}$, sample TS-35-AB). Multiple nucleation took place and irregularly formed crystallites were found.

From the examples AD to AG (see Table 4) can be seen that a very low $\mathrm{OH}^{-} / \mathrm{Si}$ ratio gave crystallites of about $1.5 \mu \mathrm{m}$. At $\mathrm{OH}^{-} / \mathrm{Si}$ ratios of $0.30-0.35$ a minimum in the crystallite size of about $0.15 \mu \mathrm{m}$ was observed. If the $\mathrm{OH}^{-}$ concentration was further increased larger crystallites were found. From all SEM pictures made in this study it can be seen that high $\mathrm{OH}^{-} / \mathrm{Si}$ ratios give large crystallites, not only for these seven examples but generally when all TS1 samples prepared are taken into account. XRD shows virtually no differences for any of the samples. Because we found differences in activity between the different batches and there seems to be a trend that small crystals are most active, we decided to use the TPAOH/Si ratio of 0.35 as standard. 


\section{TABLE 4}

Sol composition of the samples which were prepared to test for the influence of the TPAOH/Si ratio on the crystallization

\begin{tabular}{llllll}
\hline Sample & $\mathrm{Si} / \mathrm{Ti}$ & $\mathrm{OH}^{-} / \mathrm{Si}$ & $\begin{array}{l}{[\mathrm{Ti}]} \\
(\mathrm{mol} / \mathrm{l})\end{array}$ & $\begin{array}{l}{[\mathrm{Si}]} \\
(\mathrm{mol} / \mathrm{l})\end{array}$ & $\begin{array}{l}{\left[\mathrm{OH}^{-}\right.} \\
(\mathrm{mol} / 1)\end{array}$ \\
\hline TS-35-AA & 33.3 & 0.35 & 0.068 & 2.26 & 0.79 \\
TS-35-AB & 33.9 & 0.53 & 0.061 & 2.06 & 1.10 \\
TS-35-AC & 31.6 & 0.22 & 0.046 & 1.45 & 0.32 \\
TS-35-AD & 35.1 & 0.11 & 0.043 & 1.52 & 0.16 \\
TS-35-AE & 35.1 & 0.33 & 0.043 & 1.52 & 0.48 \\
TS-35-AF & 35.1 & 0.54 & 0.043 & 1.52 & 0.82 \\
TS-35-AG & 35.1 & 0.76 & 0.043 & 1.52 & 1.14 \\
\hline
\end{tabular}

Short description of the samples:

TS-35-AA: Cubic crystallites of about $0.17 \mu \mathrm{m}$, very homogeneous, no coffins

TS-35-AB: Irregular formed crystallites, which consist of a lot of agglomerated crystallites. Twinned coffins which are build up to form aggregates of a total size of about $4 \mu \mathrm{m}$.

TS-35-AC: Crystallites of approximately $0.3 \mu \mathrm{m}$. Quit homogeneous. It looks as if amorphous gel is precipitated on the cubic crystallites so that the total form is like cauliflowers.

TS-35-AD: Cubic crystallites of about 1-1.5 $\mu \mathrm{m}$.

TS-35-AE: Very small crystallites of approximately $0.15 \mu \mathrm{m}$.

TS-35-AF: Spheres of $1 \mu \mathrm{m}$, very homogeneous batch.

TS-35-AG: particles of $2 \mu \mathrm{m}$.

\section{TABLE 5}

Sol composition of the samples which were prepared to test for the influence of the $\mathrm{Si} / \mathrm{Ti}$ ratio on the crystallization

\begin{tabular}{llllll}
\hline Sample & $\mathrm{Si} / \mathrm{Ti}$ & $\mathrm{OH}^{-} / \mathrm{Si}$ & $\begin{array}{l}{[\mathrm{Ti}]} \\
(\mathrm{mol} / \mathrm{l})\end{array}$ & $\begin{array}{l}{[\mathrm{Si}]} \\
(\mathrm{mol} / \mathrm{l})\end{array}$ & $\begin{array}{l}{\left[\mathrm{OH}^{-}\right.} \\
(\mathrm{mol} / \mathrm{l})\end{array}$ \\
\hline TS-16-AA & 25.0 & 0.30 & 0.057 & 1.42 & 0.48 \\
TS-33-AA & 32.7 & 0.30 & 0.044 & 1.42 & 0.48 \\
TS-50-AA & 49.0 & 0.30 & 0.033 & 1.42 & 0.48 \\
TS-65-AA & 65.4 & 0.30 & 0.022 & 1.42 & 0.48 \\
TS-98-AA & 98.1 & 0.30 & 0.014 & 1.42 & 0.48 \\
S-1-AA & $\infty$ & 0.30 & 0.000 & 1.42 & 0.48 \\
\hline
\end{tabular}

Short description of the samples:

TS-16-AA: Small crystallites of about $0.15 \mu \mathrm{m}$, agglomerated.

TS-33-AA: Homogeneous batch of small crystallites of approximately $0.15 \mu \mathrm{m}$.

TS-50-AA: Crystallites of about $0.2 \mu \mathrm{m}$, very homogeneous batch.

TS-65-AA: Small crystallites of approximately $0.15 \mu \mathrm{m}$, cubics.

TS-98-AA: Small crystallites of approximately $0.15 \mu \mathrm{m}$, cubics.

S-1-AA: Small crystallites of approximately $0.15 \mu \mathrm{m}$. 


\section{Influence of the Si/Ti ratio}

A series of measurements were carried out with constant $\mathrm{OH}^{-} / \mathrm{Si}$ ratio and with varying $\mathrm{Si} / \mathrm{Ti}$ ratios (see Table 5 ). From this series it can be seen that the $\mathrm{Si} / \mathrm{Ti}$ ratio has virtually no influence on the crystallite size nor on the XRD pattern. All crystallites are about $0.15-0.20 \mu \mathrm{m}$.

All these zeolites, having different amounts of titanium in the lattice, have

\section{TABLE 6}

Sol composition of the samples which were prepared to test for the influence of the sol concentration on the crystallization

\begin{tabular}{llllll}
\hline Sample & $\mathrm{Si} / \mathrm{Ti}$ & $\mathrm{OH}^{-} / \mathrm{Si}$ & $\begin{array}{l}{[\mathrm{Ti}]} \\
(\mathrm{mol} / 1)\end{array}$ & $\begin{array}{l}{[\mathrm{Si}]} \\
(\mathrm{mol} / \mathrm{l})\end{array}$ & $\begin{array}{l}{\left[\mathrm{OH}^{-}\right.} \\
(\mathrm{mol} / \mathrm{l})\end{array}$ \\
\hline TS-35-AA & 33.3 & 0.35 & 0.068 & 2.26 & 0.79 \\
TS-35-AH & 34.5 & 0.34 & 0.076 & 2.62 & 0.89 \\
TS-35-AI & 37.5 & 0.33 & 0.136 & 5.15 & 1.70 \\
\hline
\end{tabular}

Short description of the samples:

TS-35-AA: Cubic crystallites of about $0.17 \mu \mathrm{m}$, very homogeneous, no coffins.

TS-35-AH: Very small crystallites of about $0.11 \mu \mathrm{m}$. Cubic crystallites with rounded edges.

TS-35-AI: Very small spherical crystallites of approximately $0.09 \mu \mathrm{m}$, look like cauliflowers. Crystallites are stuck together to form large aggregates.

\section{TABLE 7}

Composition of the crystallization mixtures used for the preparation of TS-1

\begin{tabular}{lcllll}
\hline Sample & $\begin{array}{l}\mathrm{Si} / \mathrm{Ti} \\
\text { sol }\end{array}$ & $\begin{array}{l}\mathrm{OH}^{-} / \mathrm{Si} \\
\text { sol }\end{array}$ & $\begin{array}{l}{[\mathrm{Ti}]} \\
(\mathrm{mol} / \mathrm{l})\end{array}$ & $\begin{array}{l}{[\mathrm{Si}]} \\
(\mathrm{mol} / 1)\end{array}$ & $\begin{array}{l}{\left[\mathrm{OH}{ }^{-}\right.} \\
(\mathrm{mol} / \mathrm{l})\end{array}$ \\
\hline TS-10-A & 10.5 & 0.786 & 0.115 & 1.21 & 0.948 \\
TS-16-AA & 25.0 & 0.30 & 0.057 & 1.42 & 0.48 \\
TS-25-AA & 22.1 & 0.284 & 0.086 & 1.89 & 0.54 \\
TS-35-AA & 33.3 & 0.350 & 0.068 & 2.26 & 0.79 \\
TS-35-AB & 33.9 & 0.53 & 0.061 & 2.06 & 1.10 \\
TS-35-AC & 31.6 & 0.22 & 0.046 & 1.45 & 0.32 \\
TS-35-AI & 37.5 & 0.33 & 0.136 & 5.15 & 1.70 \\
TS-35-AE & 35.1 & 0.11 & 0.043 & 1.52 & 0.16 \\
TS-35-AG & 35.1 & 0.76 & 0.043 & 1.52 & 1.14 \\
TS-35-AJ & 32.7 & 0.35 & 0.044 & 1.45 & 0.51 \\
TS-50-AA & 50.4 & 0.418 & 0.041 & 2.05 & 0.86 \\
TS-65-AA & 65.4 & 0.30 & 0.022 & 1.42 & 0.48 \\
TS-70-A & 64.2 & 0.405 & 0.022 & 1.44 & 0.58 \\
TS-70-B & 64.2 & 0.405 & 0.022 & 1.44 & 0.58 \\
TS-98-AA & 98.1 & 0.30 & 0.014 & 1.42 & 0.48 \\
TS-200-AA & 140 & 0.388 & 0.010 & 1.35 & 0.52 \\
\hline
\end{tabular}


good activity and selectivity in the hydroxylation of phenol to catechol and hydrochinon. Only the reaction rates differ (because they have a different amount of active sites per gram of zeolite).

\section{Influence of the sol concentration}

Normally a rather diluted crystallization mixture is used for the synthesis of TS-1 (ca. 15\% solids). In order to prepare more TS-1 per volume of autoclave, the use of more concentrated sols was investigated. From these experiments (see Table 6) it can be concluded that high $\mathrm{SiO}_{2}$ concentrations give smaller crystallites. Very high $\mathrm{SiO}_{2}$ concentrations give rise to the formation of aggregates of very small crystalline spheres. If the silica concentration is higher than $5 \mathrm{~mol} / \mathrm{l}$, aggregates of a few millimetres consisting of crystallites of about $0.09 \mu \mathrm{m}$ are found.

Is all the titanium which is present in the crystallization mixture really incorporated in the zeolite lattice?

TS- 1 sols with compositions as mentioned in Table 7 were made according to method 1 . The products obtained were analyzed by AAS, XRD and IR, the results of which are presented in Table 8.

TABLE 8

Results of the AAS, XRD and IR analyses

\begin{tabular}{|c|c|c|c|c|c|c|c|}
\hline \multirow[b]{2}{*}{ Sample } & \multicolumn{2}{|l|}{ AAS } & \multicolumn{4}{|l|}{ XRD } & \multirow{2}{*}{$\begin{array}{l}\text { IR } \\
960 / 800\end{array}$} \\
\hline & $\begin{array}{l}\text { mol-\% } \\
\text { sol }\end{array}$ & $\begin{array}{l}\text { mol-\% } \\
\text { zeol }\end{array}$ & $\begin{array}{l}\text { a-axis } \\
(\AA)\end{array}$ & $\begin{array}{l}\text { b-axis } \\
(\AA)\end{array}$ & $\begin{array}{l}\text { c-axis } \\
(\AA \AA)\end{array}$ & $\begin{array}{l}\text { Vol } \\
(\AA)\end{array}$ & \\
\hline TS-10-A & 8.70 & 3.94 & 20.100 & 19.926 & 13.415 & 5372.5 & 1.50 \\
\hline TS-16-AA & 3.85 & 2.61 & 20.108 & 19.939 & 14.427 & 5383.3 & 1.01 \\
\hline TS-25-AA & 4.33 & 3.91 & 20.116 & 19.943 & 13.434 & 5389.4 & 1.63 \\
\hline TS-35-AA & 2.92 & 2.5 & 20.095 & 19.932 & 13.414 & 5372.8 & 1.02 \\
\hline TS-35-AB & 2.87 & 2.87 & 20.103 & 19.934 & 13.418 & 5377.0 & 1.32 \\
\hline TS-35-AC & 3.07 & 3.20 & n.d. & n.d. & n.d. & n.d. & 0.98 \\
\hline TS-35-AI & 2.60 & 3.60 & n.d. & n.d. & n.d. & n.d. & 1.23 \\
\hline TS-35-AE & 2.78 & 2.01 & 20.095 & 19.925 & 13.418 & 5372.5 & 1.26 \\
\hline TS-35-AG & 2.60 & 2.00 & 20.094 & 19.919 & 13.410 & 5367.4 & 0.89 \\
\hline TS-35-AJ & 2.72 & 2.30 & 20.086 & 19.929 & 13.404 & 5365.5 & 1.04 \\
\hline TS-50-AA & 1.95 & 1.80 & 20.086 & 19.918 & 13.406 & 5363.4 & 1.01 \\
\hline TS-65-AA & 1.51 & 1.67 & 20.082 & 19.908 & 13.400 & 5357.2 & 0.60 \\
\hline TS-70-A & 1.53 & 1.37 & 20.078 & 19.913 & 13.396 & 5355.9 & 1.01 \\
\hline TS-70-B & 1.53 & 1.52 & 20.088 & 19.923 & 13.404 & 5377.0 & 1.21 \\
\hline TS-98-AA & 1.01 & 0.80 & 20.067 & 19.907 & 13.386 & 5347.4 & 0.27 \\
\hline TS-200-AA & 0.71 & 0.77 & 20.072 & 19.913 & 13.390 & 5351.9 & 0.57 \\
\hline
\end{tabular}

n.d. not determined. 


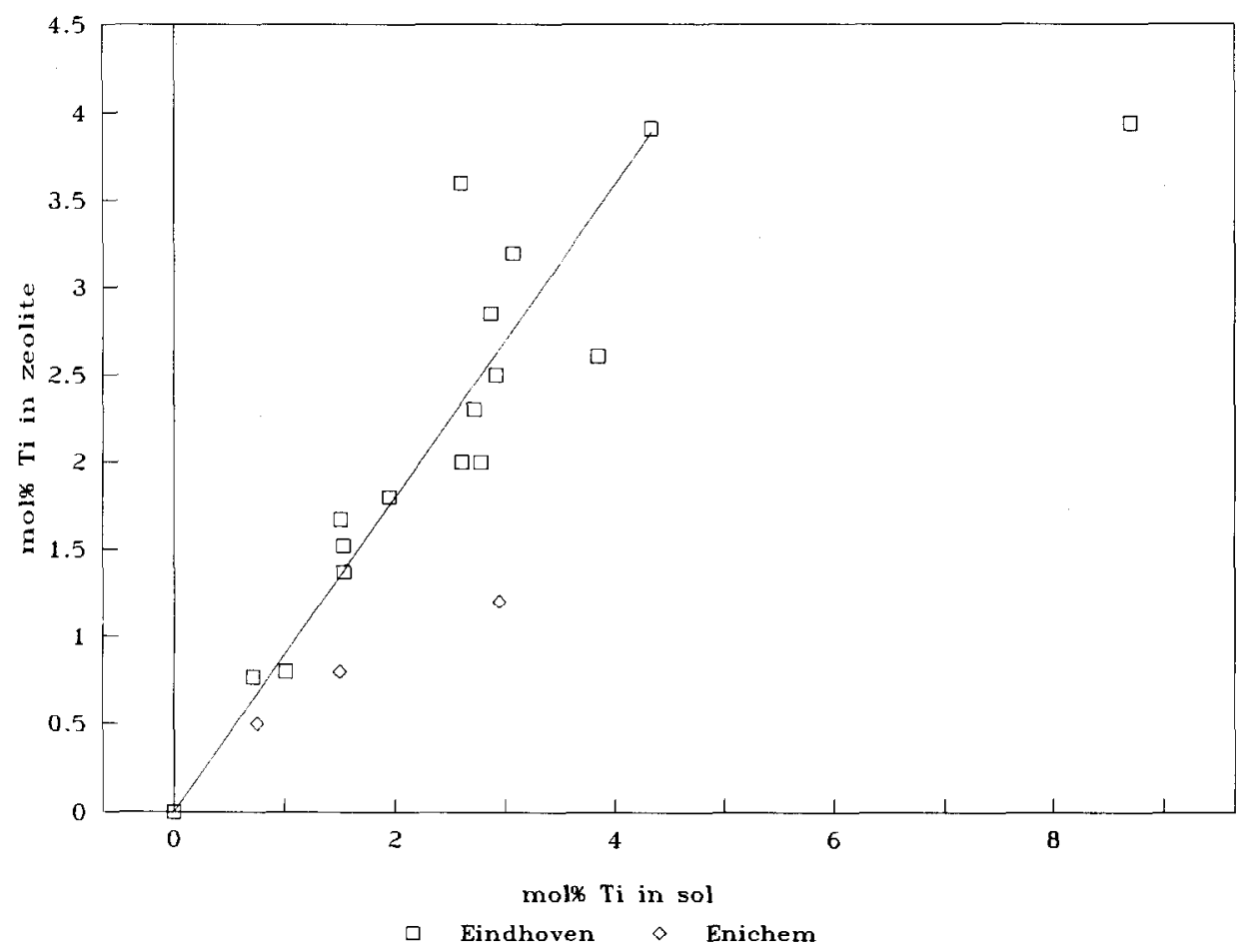

Fig. 5. Mol-\% titanium in the sol versus mol-\% titanium in the zeolite.

The product analyses using AAS give a linear relation between the $\mathrm{Si} / \mathrm{Ti}$ ratio in the sols and the $\mathrm{Si} / \mathrm{Ti}$ ratio in the well crystallized products (see Fig. 5 and Table 8). This relation is valid up to 4 mol-\% of titanium. Above this concentration the titanium is not further incorporated in the zeolite crystallites.

From these measurements it can be concluded that the $\mathrm{Si} / \mathrm{Ti}$ ratio of the crystallites is nearly the same as that of the sol. This in contrast to what is reported by Taramasso et al. [16], but in line with what we expected, as the titanium source is much more reactive than the silica source and unstable at the high $\mathrm{pH}$ values of the crystallization mixture. It therefore can be expected that all titanium will be found in the solid product and as the crystallization yield in all experiments was above $93 \%$ the $\mathrm{Si} / \mathrm{Ti}$ ratio of the crystallites will be nearly equal to that of the sol.

From the above mentioned data it can be concluded that a higher amount of titanium is incorporated into the zeolite lattice $(4.0 \mathrm{~mol}-\% \mathrm{Ti})$ than was mentioned in the patent literature $(2.8 \mathrm{~mol}-\% \mathrm{Ti})$. This high amount of titanium is completely or nearly completely incorporated in the zeolite lattice because:

- Linear curves were found if the XRD unit cell parameters versus the amount of titanium were plotted (see Fig. 6a-d and Table 8). 

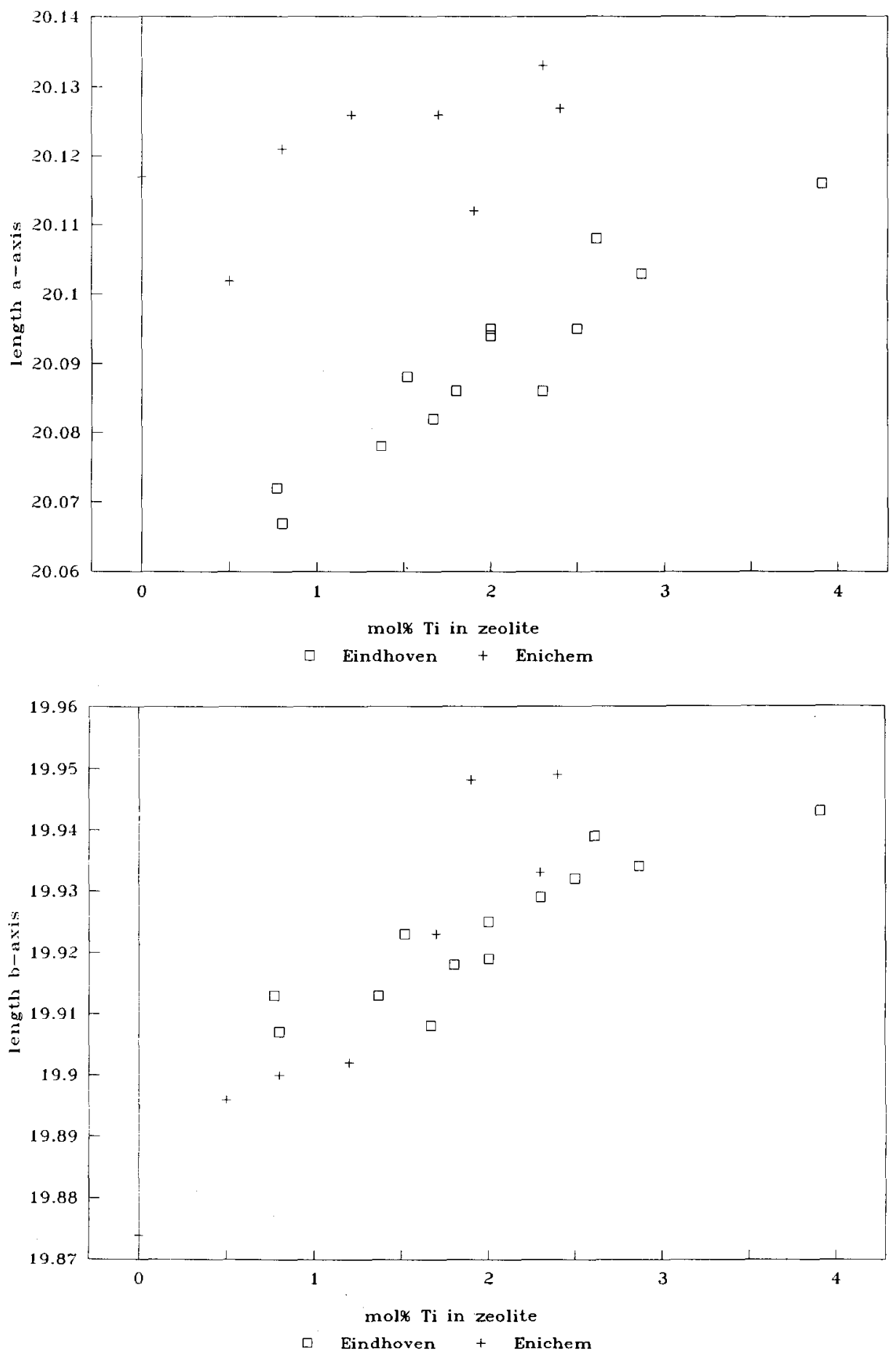

Fig. 6. ( $a, b$ and $c$ ) The length of the $a, b, c$-axis and (d) the volume of the unit cell versus the mol-\% of titanium in the zeolite. 

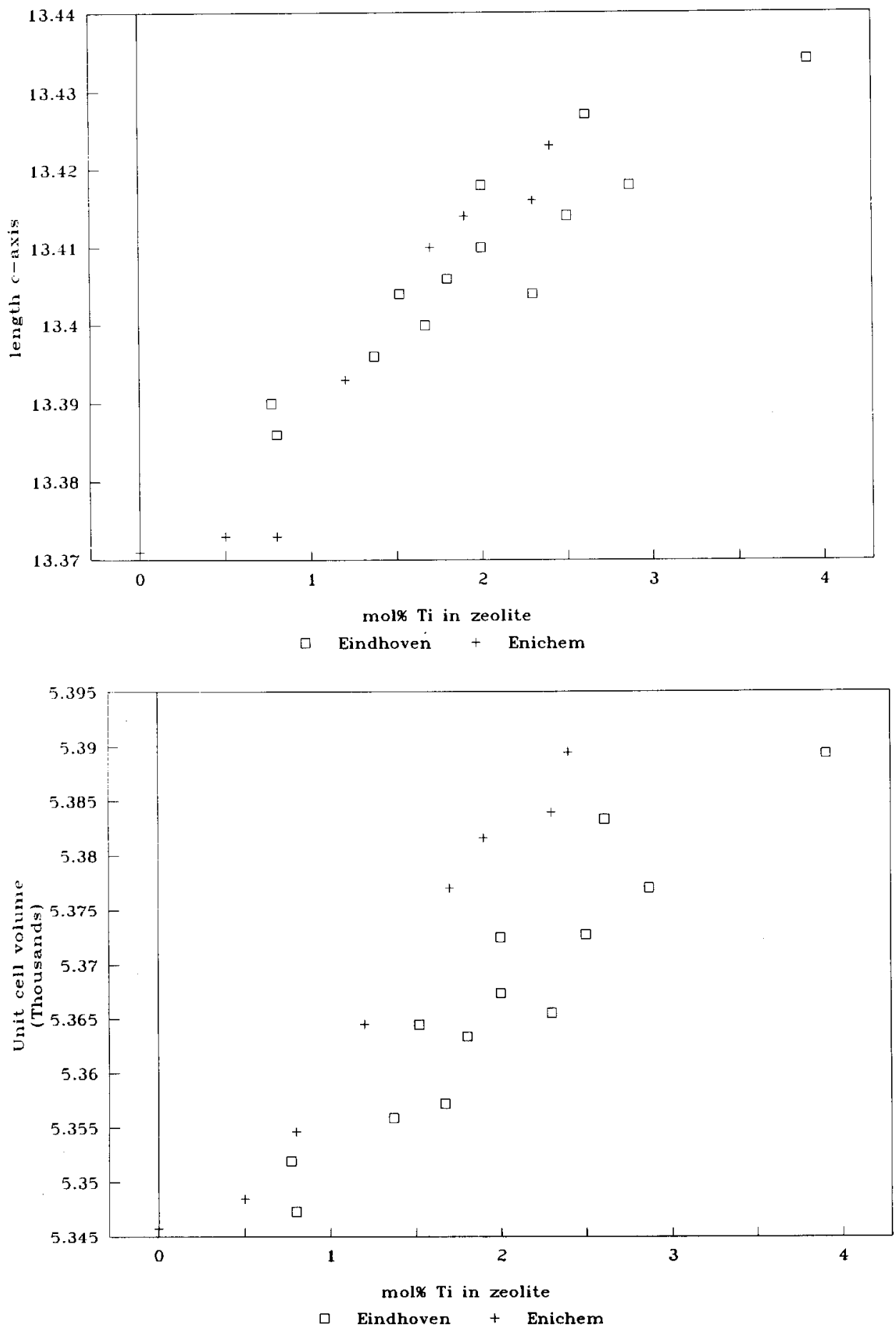


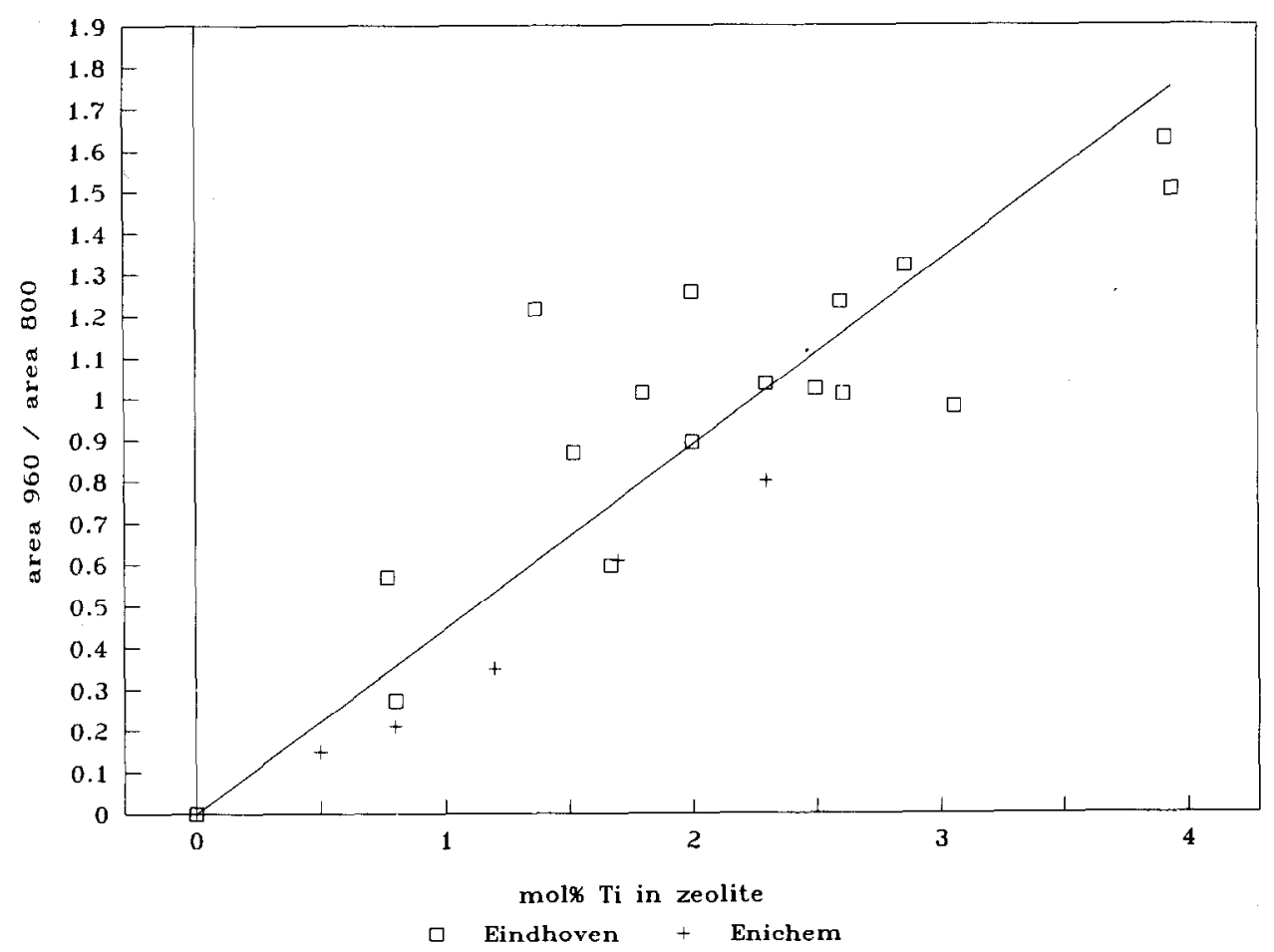

Fig. 7. The area of the $960 \mathrm{~cm}^{-1}$ peak divided by the area of the $800 \mathrm{~cm}^{-1}$ peak versus the mol-\% of titanium in the zeolite.

- A linear curve was found if the ratio between the area of the infrared 960 $\mathrm{cm}^{-1}$ peak and the area of the $800 \mathrm{~cm}^{-1}$ peak against amount of titanium was plotted (see Fig. 7 and Table 8).

Both techniques strongly suggest that up to $4 \mathrm{~mol}-\%$ titanium can be incorporated in the zeolite lattice.

Recently Thangaraj and Sivasanker [18] reported an improved method for synthesis of TS-1 with high titanium content (up to $8.5 \mathrm{~mol}-\%$ ). This clearly shows that the amount of titanium which can be incorporated in a zeolite lattice is dependent on the preparation method.

\section{CONCLUSIONS}

From the TS-1 crystallization experiments performed in our laboratory it can be conclude that:

- It is possible to synthesize TS- 1 in the range of $\mathrm{Si} / \mathrm{Ti}=24$ to $\infty$ (0 to $4 \mathrm{~mol}-$ 
\% $\mathrm{Ti}$ ) with crystallite sizes of 0.09 to $12 \mu \mathrm{m}$, high crystallinity (XRD) and good IR spectra.

- TEOS is the best starting material for preparing highly crystalline TS-1 with small crystallite size.

- The best results are obtained when TPAOH with low alkali content is used (especially TPAOH from Alfa).

- High $\mathrm{OH}^{-}$concentration causes the formation of large crystallites (speeds up the growth rate).

- High $\mathrm{SiO}_{2}$ concentration causes the formation of small crystallites (high concentration of crystallization nuclei and/or slows down the growth rate of the crystallites).

\section{ACKNOWLEDGEMENTS}

The authors thanks J.P. Verduyn and W. Mortier from Exxon Chemicals B.V. Holland for their help in the large scale autoclave experiments and the Netherlands Organization of Scientific Research (N.W.O.) for financial support.

\section{REFERENCES}

1 A. Esposito, C. Neri, F. Buonomo and M. Taramasso, UK Patent 2116974 B (1985).

2 A. Esposito, C. Neri and F. Buonomo, Offenlegungsschrift DE 33,09,669 A1 (1983).

3 A. Thangaraj, R. Kumar and P. Ratnasamy, Appl. Catal., 57 (1990) L1-L3.

4 T. Tatsumi, M. Nakamura, S. Nagishi and H. Tominaga, J. Chem. Soc., Chem. Commun., (1990) 476-477.

5 D.R.C. Huybrechts, L. De Bruyker and P.A. Jacobs, Nature (London), 345 (1990) 242-243.

6 M.G. Clerici and U. Romano, Eur. Patent 0230949 A2 (1987).

7 C. Neri, B. Anfossi and F. Buonomo, Eur. Patent 0100119 A1 (1983).

8 C. Neri and F. Buonomo, Eur. Patent 0102097 B1 (1986).

9 C. Neri and F. Buonomo, Eur. Patent 0100117 A1 (1984).

10 A. Esposito, C. Neri and F. Buonomo, Eur. Patent 0102655 A2 (1984).

11 B. Notari, in P.J. Grobet, W.J. Mortier, E.F. Vansant and G. Schulz-Ekloff (Editors), Innovation in Zeolite Materials Science (Studies in Surface Science and Catalysis, Vol. 37), Elsevier, Amsterdam, 1987, pp. 413-425.

12 R.A. Sheldon, in G. Centi and F. Trifiró (Editors), New Developments in Selective Oxidation (Studies in Surface Science and Catalysis, Vol. 55), Elsevier, Amsterdam, 1990, pp. 1-32.

13 L.-Y. Hou, L.B. Sands and R.W. Tompson, in G.C. Bond, P.B. Wells and F.C. Tompkins (Editors), Proc. 6th International Congress on Catalysis, Elsevier, Amsterdam, 1976, p. 239.

14 Kuei-Jung Chao, Tseng Chang Tasi and Mei-Shu Chen, J. Chem. Soc., Faraday Trans. 1, 77 (1981) 547-555.

15 F-Y.Dai, M. Suzuki, H. Takahashi and Y. Saito, in G.C. Bond, P.B. Wells and F.C. Tompkins (Editors), Proc. 6th International Congress on Catalysis, Elsevier, Amsterdam, 1976, p. 223.

16 M. Taramasso, G. Perego and B. Notari, U.S. Pat. 4410501 (1983).

17 G. Bellusi, A. Giusti, A. Esposito and F. Buonomo, Eur. Pat. 226257 A2 (1987).

18 A. Thangaraj and S. Sivasanker, J. Chem. Soc., Chem. Commun., (1992) 123-124. 